\title{
Modeling climate change impact on health and migration: A systematic review
}

\author{
D. Abdoul Karim Zanhouo (ib ${ }^{1}$ A. Berenger Ismael Nana (i] ${ }^{2}$
}

Received: 08.03.2019; Revised: 11.05.2019; Accepted: 27.05.2019

In addition to the many economic consequences, climate change alters migration and human health. However, while there are many models in the literature to analyze the economic shocks of climate change, authors still face many difficulties in finding appropriate models for studying the migration and health consequences related to climate change. In this article, a systematic review method is utilized to examine the modeling techniques used in studies about the influences of climate change on migration and health in recent literature. A total of 32 published studies in the last 20 years are reviewed with a focus on the modeling techniques using to study the relationship between climate change, migration, and health. The results of our analysis show that linear regression models, general equilibrium models, agent-based models, and Bayesian models are among the most widely used models in the literature of climate change effect on health and population displacements. In addition, the temperature level, the rainfall quantity, and air quality are the most used climatic change indicators in empirical studies. Moreover, the empirical findings of the review indicate that climate change will increase population mobility and increase the risk of diseases such as malaria, asthma and gastric diseases. It is also estimated that climate change will increase temperature-related death.

JEL codes: F22, Q51, Q54, I22

Keywords: Climate change, health, migration, modeling, systematic review

\section{Introduction}

The latest Intergovernmental Panel on Climate Change report (IPCC, 2018) points out that global warming has already reached the level of $1 \pm 0.2^{\circ} \mathrm{C}$ over pre-industrial quantities due to human activities (MassonDelmotte et al., 2018). As a result, the

a Department of Economics, Anadolu University, Eskisehir, Turkey (e-mail: zanhouo226@anadolu.edu.tr)

b Corresponding Author: Department of Economics, Anadolu University, Eskisehir, Turkey (email: aymarnanabi@anadolu.edu.tr). risks of impact on health, economic activity, and food security will increase in the next few years compared to their current level. Since then, researchers have tried to measure the social and economic consequences of climate change. Many models exist today to evaluate the economic effects of climate change. These models include integrated evaluation models, econometric models, Ricardian models, etc. Integrated models consist of a multi-sectoral assessment of the effects of climate change considering all economic activities. The econometric models, for their part, regress an indicator of 
economic activity such as GDP or GDP per capita on a set of climate variables such as temperature level and precipitation. Climate change will also have an impact on health indicators and population migration. For instance, McMichael et al. (2001) show that climate change could affect health indicators in three ways: Firstly, there are the impacts of climate change that are directly related to weather conditions. Secondly, through the environmental variation. Finally, by the channel of the economic effects of climate change. On another hand, the IPCC (2018) in its last special report indicates that the exposure to higher temperatures is likely to be the channel by which, climate change will affect health outcomes. Therefore, it is essential to analyze and quantify the effect of climate change on health outcomes in order to find adaptation and mitigation strategies. However, there is an insufficient number of studies on this subject (Pachauri et al., 2014), because of difficulties to determine the connection between climate change and health outcomes. Migration, which has generally economic, political, security, and other causes, will be also touched by climate change through various channels. Numerous studies in the literature have attempted to explain the link between climate change and migration. For example, Marchiori et al. (2012), studying the impact of weather variation on migration, show in a cross-countries study that temperature and rainfall shocks caused a global net migration of five million individuals between 1960-2000. In consequence, at least of 128,000 people will be affected every year. However, finding an appropriate model to analyze climate change impact on health and population migration still a subject of debates.

The objective of this paper is to examine the recent literature about the modeling of climate change effect on health and migration. We review 32 published papers in the last two decades on the modeling of climate change impact on health and population migration. These studies include journal arti- cles, working papers, reports, books' chapters, and books. After screening abstracts, 32 articles fulfilled our criteria. Among them, 18 are linking to modeling climate change effects on population migration and 14 are related to the health impacts of global warming. The sample of studies is presenting in table 1 in appendix. The rest of the article is as follow. In section II, we describe the theoretical modeling strategies used to analyze the effect of global warming on health and migration and section III exposes the mains results of the articles reviewed.

\section{Modeling climate change impact on health}

To analyze climate change impact on health, it is necessary to consider several features related to methodological strategies. Indeed, authors facing many methodological difficulties due to a limited understanding of the complex pathways through which climate change will impact health outcomes. Many questions rest unanswered. These questions include: What are the climatic factors that will affect health? What are the health indicators that will be particularly affected? How to measure the link between climate change and human health? In the literature, many authors have attempted to provide answers to these questions, but many shadow points remain. In this section, before reviewing the empirical results obtained in the articles dealing with the analysis of the effects of climate change on human health, we will first review models and methodologies used.

\subsection{Methodology aspects}

\subsubsection{Health outcomes measurement}

In the literature, researchers have focused on several diseases and health indicators, which they believe climate change could affect. Among these diseases, there are ozone-related diseases, malaria, and diarrhea. Knowlton et al. (2004) and Sheffield et al. (2011) in their articles respectively analyze ozone-related mortality and emergency 
visits for asthma problems in the population of children under 17 years of age. For their part, Caminade et al. (2014) and Parham and Michael (2010) examined the effects of climate change on malaria risk and transmission rate. Other scholars, such as Deschenes et al. (2009), Jankowska et al. (2012), consider the influences of climate change on children especially on birth weight, malnutrition, stunting, and anemia problems. The risk of bacterial diseases caused by climate change is also investigated by Bambrick et al. (2008) in the literature. These are the health indicators that have been analyzed in the current literature. Authors try to analyze climate change impact on these health variables using different scenarios of climate change.

2.1.2 Climate change modeling and scenarios

For analyzing climate change impact on health, it is crucial to distinguish the different factors of climate change that will influence human health. Among these factors, temperature level, rainfall quantity, and ozone concentration are widely used as the channels through climate change altering health. However, there are still many challenges in quantifying these indicators. Authors generally use historical and future data in their analysis. However, while it is easy to find historical data, predicting climate change future indicators remains a very complex task. In estimating expected climate change, many models and scenarios are used. Knowlton et al. (2004), in their study, use global and regional models to simulate the level of ozone concentration in different parts of the US. Indeed, the global model of Goddard Institute for Space Studies (GISS) is first utilized to produce simulations of the hourly climate on the global level over the period 1990 to 2100. The A2 scenario of IPCC is using for simulating the level of greenhouse gas emissions. The results of this global model estimates are then employing in the Penn State / National Center for Atmospheric Research Model Mesoscale Model
5 (MMC5) for determining climate factors at a regional level. Then, $\mathrm{O}_{3}$ (ozone) concentration is estimated using the Community Multiscale Air Quality method. Ozone concentration is later used in a formula to compute the variation in $\mathrm{O}_{3}$-related mortality in the period from 1990 to 2050. Sheffield et al. (2011) employ the same methodology as Knowlton et al. (2004) to analyze the impact of climate change on Childhood Asthma in New York City. However, in most studies on climate change impact on health, the authors use predictions of temperature and rainfall levels.

For instance, Deschenes et al. (2009) in their article use daily temperature over the 20702099 period predicted by the National Center for Atmospheric Research Community Climate System Model (CCSM3). CCSM3 is a climatic model that has sea ice, atmosphere, ocean, and land as main components. These components are linked to each other through flows to simulate the past, present and future climate change at lower cost on large spatial resolution (Van Oldenborgh et al., 2005).

Jankowska et al. (2012) in the same vein use precipitation and temperature obtained by simulations of the FEWS-NET Climatology (FCLIM) model. The FCLIM precipitation and temperature measures incorporate climate, satellite and physiographic data and use as inputs the station and satellite observations and physiographic predictors. The result of the FCLIM model predictions is a water balance index that indicates the amount of humidity of the soil (Jankowska et al., 2012). This indicator is called the Potential Evapotranspiration (PET). It takes positive values for wet soil and negative values for dry land. Later, PET is employed to analyze the livelihood zones, and three indicators of children malnutrition such as stunting, anemia, and underweight.

Caminade et al. (2014) for their part, used five climate models from the Coupled Model Intercomparison Project Phase 5 (CMIP5) to obtain temperature and precipitation data for their study, which aims to analyze the 
link between climate change and malaria transmission. HadGem2-ES, IPSL-CM5ALR, MIROC-ESM-CHEM, GFDL-ESM2M, and NorESM1 models are using to obtain a wide variability of temperatures and precipitations.

Still in the category of authors who have studied the relationship between climate change and health using predictions of temperature and precipitation as climatic factors, Parham and Michael (2010) used the temperature and precipitation level obtained through the global climate model, HadCM3. The HadCM3 model (HadAM3) is a climate model produced at the Hadley Center in the UK. It is used for simulations over long periods with limited variation in its surface climate.

Finally, Bambrick et al. (2008), used maximum temperatures and daily precipitation from all Australian observation stations to estimate daily climate of each area for statistical divisions. These temperature and precipitation levels are then using as input to a model to estimate the relationship between mortality rate and the maximum temperature level per day. The authors then use different methods and models to analyze the link between climate factors and health outcomes. In the following section, we will discuss some of these methods used in the literature.

\subsubsection{Methods and models}

Unlike studies on the effects of climate change on economic indicators, where many models and methods exist for analyzing, in the studies on the health effects of climate change there are many obstacles in finding the appropriate model to quantify the health impact. Linear and nonlinear regression are often used in these studies. Jankowska et al. (2012) and Deschenes et al. (2009) used linear regression models in their studies. For instance, Jankowska et al. (2012) used a multilinear regression to analyze the impact of temperature and precipitation on three indicators of childhood malnutrition in Mali.
Deschenes et al. (2009) have regressed the birth weight of children on climatic variables such as temperature and precipitation. Bambrick et al. (2008) made use of poison regression to investigate the influence of maximal temperature and precipitations on some health indicators such as temperaturerelated mortality, hospitalizations, salmonellosis, and bacterial gastroenteritis. Other authors, on the other hand, have simply applied mathematical specifications to assess the risk of diseases linked to climate change. Knowlton et al. (2004) and Sheffield et al. (2011) used the following formula to quantify the effect of ozone concentration caused by climate change on health problems.

$$
M=\left(\frac{P}{100000}\right) * B * C R F * E
$$

where $\mathrm{M}$ is the number of deaths in a day attributable to ozone $\left(\mathrm{O}_{3}\right)$ concentration. $\mathrm{P}$ represents county population predicted during the time period; $\mathrm{B}$ is the baseline rate at county-level mortality per day and CRF is the concentration-response function.

Knowlton et al. (2004) use this formula to compute the mortality rate caused by $\left(\mathrm{O}_{3}\right)$ concentration in 1990 and predicted rate in 2050 in the summer season. Sheffield et al. (2011) use the same equation to analyze the number of emergency department visits by children aged 0-17 years due to $\left(\mathrm{O}_{3}\right)$ related asthma in the 2020 s compared with the $1990 \mathrm{~s}$.

Parham and Michael (2010) first, calculate the number of mosquito $(\mathrm{M})$ as a function of rainfall and temperature. Then, the basic reproduction number $\mathrm{R} 0$ of malaria is computed according to the below formula (2).

$$
R_{0}=\frac{M(R, T) a(T)^{2} b_{1} b_{2} l_{M}(T)}{\gamma \mu(T) N}
$$

where $M$ is the number of mosquitoes, $T$ and $R$ indicate temperature and precipitation respectively; a is for the biting rate per day per mosquito , $b_{1}$ is the proportion of bits by vulnerable mosquitoes on infectious hu- 
mans that produce infection, $b_{2}$ is the rate of bites by contagious mosquitoes on vulnerable humans that produce disease, $l_{M}$ is the percentage of infected mosquitoes that become infectious, $\gamma$ is the rate at which infectious humans recover and acquire immunity, $\mu(T)$ is the everyday mortality ratio of adult mosquito (Parham \& Michael, 2010).

\subsection{Empirical findings of the effect of climate change on health outcomes}

The empirical results of different articles included in this review differ not only according to the modeling of climatic and health factors but also according to the scenarios adopted in the prediction of the future climate change. While some authors have adopted moderate scenarios of climate change, others have preferred extreme situations of climate change. Caminade et al. (2014), in their article on the effects of climate change on the global distribution of malaria, used multi-malaria (multiple malaria indicators) and multi-scenario models. The results of their study predict an increase of malaria suitable climate and a rise in the number of people at risk. However, they emphasize that the results are very sensitive to the adopted climate model and malaria indicators.

In the same vein, Parham and Michael (2010) have examined the effects of climate conditions on malaria transmission in Tanzania. In their analysis, they first used the HadCM3 climate model to predict the temperature and precipitation levels. Then these climatic data are used to estimate the number of mosquitoes and the basic breeding numbers of malaria. In their study, they show that extinction is more influenced by precipitation than by temperature. A temperature window of approximately 32 to $33^{\circ} \mathrm{C}$ has also been identified as one in which endemic transmission and expanse rate in disease-free areas are optimized.

Analyzing the impact of climate change on health, Knowlton et al. (2004) examine the influence of air quality on the rate of mor- tality linked to the concentration of ozone in the air. They show that climate change will lead to an increase in ozone-related mortality with a median growth rate of $4.5 \%$ between 1990 and 2050 in the 31 counties included in their study. In addition, the inclusion of the population growth effect reduces this rate to $4.4 \%$.

Sheffield et al. (2011) study the relationship between regional climate change, ozone concentration, and childhood asthma in New York City. The results of their analysis suggest that in 2020 compared to the 1990s, ozone concentration could lead to an average growth of $7.3 \%$ of emergency department visits for asthma problems among children from 0 to 17 in the metropolis of New York. Similarly, Knowlton et al. (2004) study states that while the inclusion of changes in ozone precursors may decrease the impact, considering population growth could increase the impact.

Still, in the category of studies using air quality as a factor of climate change, Tagaris et al. (2009) examined the potential effects of pollution on human health in the US. Testing specifically the role of ozone concentration and PM2.51, they have shown that PM2.5 will have more negative health effects than ozone concentration. Indeed, their study reveals that PM2.5 will induce precipitate mortality 15 times higher than the $O_{3}$. In addition, PM2.5 is predicted to generate around 4000 premature deaths annually in the US, while ozone will create only about $300 \mathrm{annu-}$ ally.

Deschenes et al. (2009) looked at the relationship between climate and birth weight in the USA in their study. Regressing the birth weight on a number of climatic variables, they find that exposure to a very high ambient temperature during pregnancy could lead to a decrease in the baby's birth weight and increase the likelihood of having low birth

1 PM2.5 refers to atmospheric particulate matter (PM) that have a diameter of less than 2.5 micrometers, which is about $3 \%$ the diameter of a human hair. https://blissair. com/what-is-pm-2-5.htm 
weight. For example, the weight of white babies will drop by $0.22 \%$, while the weight drop will reach $0.36 \%$ among black at the end of the century due to climate change.

Jankowska et al. (2012) ascertain in their study that climate change will highly affect childhood malnutrition. Indeed, they show that Mali climate which is characterized by a PET $<-100$ will increase underweight and stunting for children. For instance, they conclude that by 2025 , the projected climate will expose one million children to the risk of malnutrition and livelihood change. However, this climate will positively influence children anemia.

Bambrick et al. (2008) study the effect of climate change on some health's indicators namely, mortality and hospitalization related to temperature, salmonellosis, gastric diseases, and the number of population at risk of dengue. They show that climate change will have negative effects on all the indicators. Indeed, according to the study, climate change will lead to an increase in the number of gastroenteritis cases by the end of the 21st century, given the positive impact of climate on pathogenic bacteria. For illustration, it is estimated that climate change in different scenarios will annually cause between 205,000 and 335,000 cases of the gastric disease. In addition, they show that climate change will increase the number of temperature-related deaths and hospitalization in Australia notably in Queensland and in the western and northern parts of the country.

Finally, some authors study directly the relationship between climate change and mortality rate. For instance, Curriero et al. (2002), in their article, analyzed the effect of temperature on mortality in 11 cities of the United States of America. The log-linear model applied to time series was used in their study. They show that there is a strong relationship between mortality and temperature level in the 11 cities examined. Also, they demonstrate that there is an inverse relationship between temperature and the risk of mortality up to a certain threshold beyond which an increase in temperature increases the risk of mortality. The authors also showed that the relationship between temperature and mortality is also related to latitude. They point out that the impact of cold temperatures on mortality is more marked in the Southern zone, while that of warm temperatures is further in the North. The World Health Organization (WHO) (2014), in its report, estimates the risk of death related to climate change. They respectively evaluate the mortality related to heat, costal flood, diarrhea disease, Malaria, Dengue, and undernutrition. In the report, it is anticipated that heat wave will cause 65,000 extra deaths by 2030 in elderly population in case the absence of adaptation. In addition, Diarrhea and Malaria will respectively create 48,000 and 60,000 deaths by 2030 . However, it supports that the costal flood effect can be avoided with a perfect adaptation. Furthermore, the number of deaths related to Dengue fever is predicted to be insignificant. To sum up, many works were carried to investigate the impact of global warming on health indicators. However, modeling problems still ongoing and lead to different results in empirical studies.

\section{Modeling climate change on people migration}

In addition to the economic and health impact of global warming, Greenhouse Gas (GHG) will also have social effects such as population migration and violent conflict. Human migration is the movement of people from one place to another. It can be from rural areas to urban centers or from one country to another. It usually has economic, political, security, and other causes. Climate change can lead to population migration across multiple channels. Despite the great interest in studying climate change and migration relationship, few studies have used statistical methods to present migration as a potential social outcome of climate change in the past (Galloway, 1986). Below we discuss the methods recently used in the literature 
to analyze the effects of climate change on people migration.

\subsection{Review of theoretical models}

In the literature, many models were developed to analyze the impact of global warming on people migration. These models go from simple survey to a complex model such as computable general equilibrium models.

Agent-Based Model (ABM) is one of the most used in the literature related to climate change and migration questions. This model has the particularity of being more intuitive than mathematical or statistical models in that it represents objects as we see them. Agent-based modeling is increasingly using to conceptualize, model and simulate problems related to social sciences. This method is used in ecology, geography, economics, sociology, archeology, or psychology. The model allows building an integrated migration model sensitive to social, economic and environmental factors while considering the disparity among migrants and the dynamics of migration. Authors such as Kniveton et al. (2011) and Hassani-Mahmooei and Parris (2012) use ABM to analyze migration effect of climate change.

Climate change can negatively affect the agricultural sector through a decline in production and productivity, and this will result in an incentive for the population to migrate if the mechanisms of adaptation are not met. Barbieri et al. (2010), to better understand the conditions in which migration decisions are made in Brazil, used an integrated economic-demographic-climate model combining with Population Projection Models, a Computable General Equilibrium Model and the projected climate changes in Brazil (see the fig. 1). The model emphasizes the critical relationships between climate change and economic dynamics and their impact on population migration. This study shows that these innovative models, which make it possible to understand the relationship between climate change, economy, and migra- tion, represent only a small part of the potential impacts in the North-East of Brazil. Geostatistical interpolation methods were used by Nawrotzki et al. (2015) in their study on the effects of climate change on migration to the United States from rural and urban areas of Mexico. The geostatistical interpolation method is used to interpolate or predict values at unsampled locations, in the same way as with deterministic interpolation. Nawrotzki et al. (2015) employ the geostatistical interpolation method to develop two indices of climate change, that capture the duration of a wet and warm period based on daily temperature and precipitation data. These data are then used to analyze the effect of climate change on household-level migration. As future climate change is a random phenomenon, some authors have opted for probabilistic models in their studies. Therefore, the Bayesian model has been used by some authors to analyze the effects of climate change on migration. For instance, Abel et al. (2013) investigates the possibilities of predicting uncertainty about the level of immigration in the United Kingdom as a result of environmental factors using Bayesian models. The Bayesian method is used most often to manage forecast uncertainties. This is an advantageous approach compared to conventional approaches to forecasting migration (Bijak, 2010). In fact, to manage uncertainties, this approach uses probability distributions to provide a range that indicates the degree of possibility around the central trajectory (Abel et al., 2013). Also, with Bayesian models, it is possible to integrate expert opinions into projections in the form of earlier distributions (Bernardo et al., 2003). The Bayesian process can be summarized as in figure 2 .

In addition to the complex models discussed above, some authors have used simpler models to analyze the relationship between climate change and migration. Feng et al. (2010) and Iqbal and Roy (2015), for example, used instrumental variable econometric models to examine the effect of cli- 


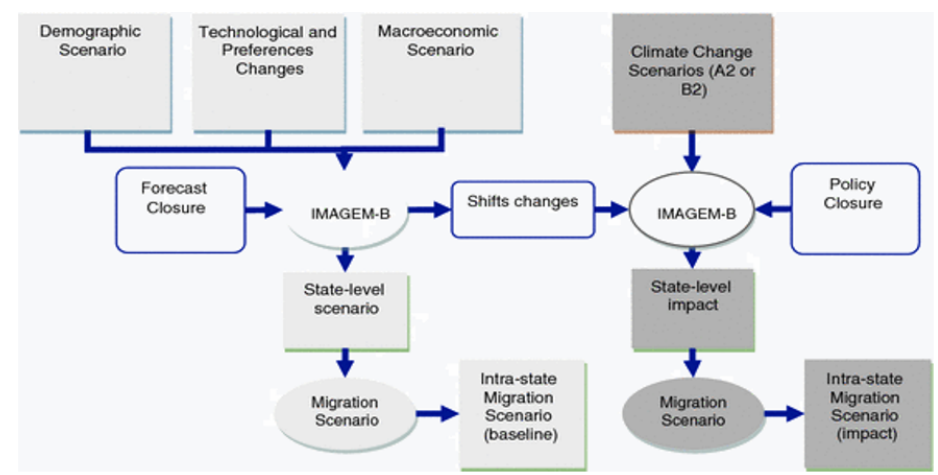

Figure 1: Integrated model of economic, demographic and climate scenarios(Barbieri et al., 2010)

mate change on immigration between Mexico and the US and in Bangladesh, respectively. Finally, statistical questionnaires were also used by the authors to analyze the connection between climate change and migration. Mortreux and Barnett (2009) conducted semi-structured interviews with the residents of Funafuti (Tuvalu Island) on the issue of emigration. Out of the total of interviewees, it appears that climate change is not cited as a reason to migrate. In other words, the effects of climate change do not cause migration.

Also, in Tanzania, individual data from the national survey of Tanzania are used to investigate the likely role of droughts or floods, crop diseases and severe water shortages on migration Ocello et al. (2015). In this study, a total of 03 different questionnaires were submitted: a multi-topic questionnaire on households, a community questionnaire, and a questionnaire focused on agriculture. The logit model is used to determine the impacts of environmental shocks on inter-district migration. To sum up, many models can be found in the literature analyzing the effect of climate change on migration. However, there are still uncertainties in predicting climate change and establishing the link with people migration.

\subsection{Empirical findings on the effect of climate change on migration}

Black et al. (2011) identified 5 groups of factors that affect migration decisions. These factors include economic, political, social, demographic and environmental factors. The latter is very dependent on other factors and can directly or indirectly affect migration decisions. We can classify them all in three different approaches: A micro/individual approach focused on the individual's desires and expectations, a macro/structural approach which lies on the economic structure of country and individuals and does not control structural components, which limits their actions. A meso-level of migration decisions consider both structural and individual approaches like family ties, peer group, social networks and isolated minority communities. Many empirical studies have look at the relationship between climate change and human migration.

In a study by Nawrotzki et al. (2013), it is shown that a decrease in precipitation would significantly lead to migration to the United States only in dry Mexico. In other words, there is a significant link between the rainfall deficit and international migration only in dry states in the north of the country. However, this result is contrary to that found in the humid regions of eastern and southern Mexico. In this part of the country, social networks are the main reason for the population movement. Furthermore, Nawrotzki et al. (2015) in other study found that international migration from Mexico between 1986 and 1999 has increased due to heat waves and wet periods. However, this flow of international migration is observed only in rural 


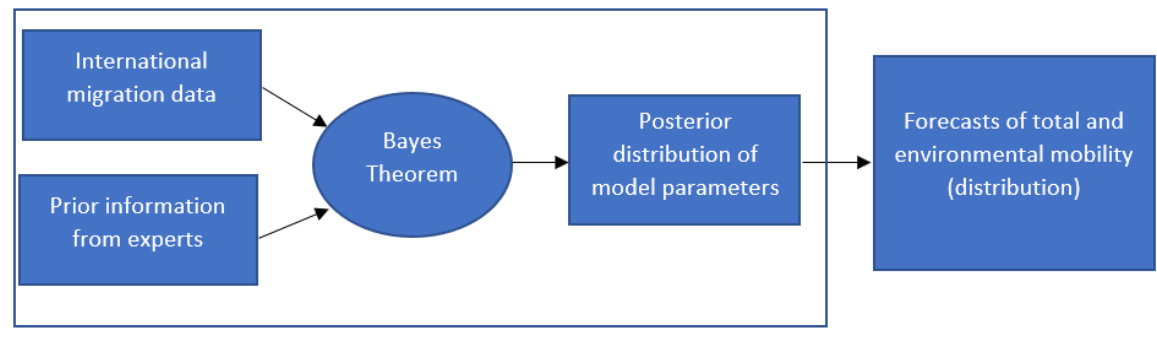

Figure 2: The Bayesian approach to forecasting environmental mobility and assessing the uncertainty associated with the forecasts (Abel et al., 2013)

areas.

Similar results are found in Bangladesh with the study by Hassani-Mahmooei and Parris (2012). According to them, climate change is likely to affect migration by increasing internal displacements to the districts (northeast and east) least affected by floods and drought. Also, it is necessary to add that it is the urban areas that absorb the most migrants. They point in their research that this migration will affect between 3 and 10 million people in the next 40 years, depending on the severity of the risks.

Jennings (2015) study the relationship between climate and migration in the Netherlands from 1865-1937. Their study reveals that the internal migration of certain social groups at the end of the period is related to negative climatic conditions and on the other hand, the flow of international movements drops with extreme rainfall.

Marchiori and Schumacher (2011) reported that even a small variation of climate change has significant effects on the number of migrants. Indeed, referring to a calibration exercise that states that the number of migrants increases by a factor of four when climate change lead to a reduction of southern productivity by about $5 \%$. With climate change, many regions, particularly parts of Africa, Bangladesh, India, Australia, and Latin America, are expected to experience a substantial reduction in agricultural yields. Feng et al. (2010), in their study of the nexus between climate change, crop yields, and Mexico-US cross-border migration, they quantitatively examined the relationships between crop yields, climate variations and population migration. They conclude that, by 2080 , climate change will result in the emigration of 1.4 to 6.7 million adult Mexicans ( 2 to $10 \%$ of the current population aged 15 to 65$)$ solely because of reduced agricultural productivity. Other authors find that changes in agricultural productivity caused by climate affect the rate of migration. Indeed, according to Iqbal and Roy (2015), one standard deviation of real per capita income increased net migration rates from $1.4 \%$ to $2.4 \%$. The results obtained with fixed effects (FE) and instrumental variables (IV) show that the uncertainty related to temperature and precipitation variations affects migration through agricultural productivity. In Northeast of Brazil, the projected climate shocks will severely impact the region's agricultural sector, while acting as a potential factor of migration in some parts of the country (Barbieri et al., 2010). Climate change is probably presented as a probable migratory factor, especially in dry areas of developing countries. For example, through a survey of 104 farmers, Meze-Hausken (2000) showed that migrants place the continuing drought in the northern region of Ethiopia at the forefront of this movement. It should also be noted that vulnerability to climate change is a complex problem, but this does not make these people potential migrants, as they have been able to develop adaptation mechanisms to cope with slow climatic variations and events. In the same vein, Cattaneo and Massetti (2015) show that climate change affects rural migration in Nigeria and Ghana, 
specifically for farm households. Indeed, they demonstrate that there is a relationship between dry season temperature and the propensity to migrate and between wet season rainfall and the propensity to migrate. However, in non-agricultural households the results are inconclusive. This suggests that climate affects migration through the effect of climate change on agricultural productivity. For Kniveton et al. (2011), the shift to a more arid environment creates significant migration flows when coupled with connected and inclusive social and political governance changes. While in a wetter climate, international migratory movements are low with diverse and exclusive governance scenarios. Fussell et al. (2014) observe an increase in population movement to safer areas after disasters such as Hurricane Katrina in the city of New Orleans. The results show that after the disaster, New Orleans migration system experienced a flow of migrants from neighboring counties in the coastal region of the Gulf of Mexico. Their research also shows that the migration system was based on its stronger links with neighboring and less affected counties to rebuild its population.

Ocello et al. (2015) study support the "environmental scarcity" hypothesis, which shows that droughts, floods, and crop diseases are linked to an overall decrease in the risk of internal migration in Tanzania. This study reveals also that population movement is an essential livelihood strategy for the most disadvantaged as migration is a likely response to drought and floods among uneducated people. In other words, in Tanzania, migration is discriminating in that the links between migration and adverse environmental conditions differ according to the level of education of the people. People with a low level of literacy are more likely to migrate than those with a high level of education.

The study by Black et al. (2011) shows that individual migration decisions and flows are due to the influence of factors such as the availability and credibility of ecosystem services and exposure to different climatic haz- ards. Environmental changes can have a direct impact on the dangerousness of places and indirectly affect migration through economic, political and social factors. Thus, future environmental changes will not cause migration flows but will amplify (or modify) existing demographic trends in migration to urban areas.

Mortreux and Barnett (2009) with their interviews on the residents of Funafuti (Tuvalu Island) show that climate change is not cited as a reason to relocate. In other words, the impact of climate change is not an important factor for those who intend to migrate. For the inhabitants, the reasons that motivate them to stay are more cultural reasons, identity, and the way of life. Thus, climate change does not seem to worry most people in Funafuti and therefore would not be a reason to leave. In the same methodological way, Martin et al. (2014), in their qualitative study conducted in Bangladesh, indicate that villagers in areas affected by climate stress and shocks adopt a livelihood strategy that is migration. In other words, migration is perceived as a social behavior that occurs as a result of climate change. We can see from the above studies that climate change affects migration in many ways and through different channels.

\section{Conclusion}

Climate change have many effects on migration and human health. Therefore, it is necessary to model these impacts and quantify them to find adaption strategies. However, in the literature, the authors still face the difficulty of finding the best modeling strategies due to many uncertainties in the prediction of future climate change.

In this review, we examine recent models and methods used for examining the relationship between climate change, migration, and health outcomes. The results of our review show that many modeling techniques are used in the literature to study the effects of climate change on migration and health outcomes. In terms of health impacts, the 
authors used linear and non-linear regression as well as specific formulas to compute certain health indicators (mortality, emergency department visits, malaria transmission rates, etc.) including climate variables as exogenous variables. The Bayesian model is also used to analyze the effects of climate change on health. For migration impacts, modeling techniques range from general equilibrium models to simple linear regressions. Agent-Based Model (Kniveton et al., 2011; Hassani-Mahmooei \& Parris, 2012), the Geostatistical Interpolation Methods (Nawrotzki et al., 2015) and the Bayesian Model are mostly used methods in the literature.

Temperature levels, precipitation, and ozone concentration were the most widely used indicators of climate change in the literature. Empirical results show that climate change will increase population movement (Nawrotzki et al., 2013; Hassani-Mahmooei \& Parris, 2012; Marchiori \& Schumacher, 2011). However, some authors (Mortreux \& Barnett, 2009) in their studies find that climate change won't affect the population's migration.

Regarding the health impact of climate change, results show that climate change will affect mortality and hospitalization related to temperature, gastric diseases, asthma, and malaria. As we can see, different modeling techniques exist in the literature and the empirical results differ according to the modeling, indicators, and regions considered.

\section{References}

Abel, G., Findlay, A., McCollum, D., \& Wiśniowski, A. (2013). Forecasting environmental migration to the united kingdom: an exploration using bayesian models. Population and Environment, 35(2), 183-203. doi:10.1007/s11111-013-0186-8

Bambrick, H., Dear, K., Woodruff, R., Hanigan, I., \& McMichael, A. (2008). The impacts of climate change on three health outcomes: Temperaturerelated mortality and hospitalisations, salmonellosis and other bacterial gastroenteritis, and population at risk from dengue. https://eprints .qut.edu.au/103231/1/103231.pdf. Economics Bulletin.

Barbieri, A. F., Domingues, E., Queiroz, B. L., Ruiz,
R. M., Rigotti, J. I., Carvalho, J. A. M., \& Resende, M. F. (2010). Climate change and population migration in brazil's northeast: scenarios for 2025-2050. Population and Environments, 31 (5), 344-370. doi:10.1007/s11111-010-0105-1

Bernardo, J., Bayarri, M., Berger, J., Dawid, A., Heckerman, D., Smith, A., \& West, M. (2003). Bayesian factor regression models in the "large $\mathrm{p}$, small n" paradigm. Bayesian statistics, 7, 733742. https://pdfs.semanticscholar.org/519f/ a62cf5f8f842d5ba8a67473e0f34bcc486d6.pdf.

Bijak, J. (2010). Forecasting international migration in europe: A bayesian view (Vol. 24). Springer Science \& Business Media.

Black, R., Adger, W. N., Arnell, S., Nigel W.and Dercon, Geddes, A., \& Thomas, D. (2011). The effect of environmental change on human migration. Global Environmental Change, 21, S3-S11. doi:10.1016/j.gloenvcha.2011.10.001

Caminade, C., Kovats, S., Rocklov, J., Tompkins, A. M., Morse, A. P., Colón-González, F. J., ... Lloyd, S. J. (2014). Impact of climate change on global malaria distribution. Proceedings of the National Academy of Sciences, 111 (9), 32863291. doi:10.1073/pnas.1302089111

Cattaneo, C., \& Massetti, E. (2015). Migration and climate change in rural africa (Working Paper Series No. 029.2015). Fondazione Eni Enrico Mattei. https://papers.ssrn.com/sol3/papers.cfm ?abstract_id=25966001.

Curriero, F. C., Heiner, K. S., Samet, J. M., Zeger, S. L., Strug, L., \& Patz, J. A. (2002). Temperature and mortality in 11 cities of the eastern united states. American Journal of Epidemiology, 155(1), 80-87. doi:10.1093/aje/155.1.80

Deschenes, O., Greenstone, M., \& Guryan, J. (2009). Climate change and birth weight. American Economic Review, 99(2), 211-217. doi:10.1257/aer.99.2.211

English, P. B., Sinclair, A. H., Ross, Z., Anderson, H., Boothe, V., Davis, C., ... others (2009). Environmental health indicators of climate change for the united states: findings from the state environmental health indicator collaborative. Environmental Health Perspectives, 117(11), 16731681. doi:10.1289/ehp.0900708

Feng, S., Krueger, A. B., \& Oppenheimer, M. (2010). Linkages among climate change, crop yields and mexico-us cross-border migration. $\mathrm{Na}$ tional Academy of Sciences, 107(32), 1425714262. doi:10.1073/pnas.1002632107

Fussell, E., Curtis, K. J., \& DeWaard, J. (2014). Recovery migration to the city of new orleans after hurricane katrina: a migration systems approach. Population and Environment, 35(3), 305-322. doi:10.1007/s11111-014-0204-5

Galloway, P. R. (1986). Long-term fluctuations in climate and population in the preindustrial era. Population and Development Review, 12(1), 124. doi: $10.2307 / 1973349$

Hassani-Mahmooei, B., \& Parris, B. W. (2012). Climate change and internal migration patterns 
in bangladesh: an agent-based model. Environment and Development Economics, 17(6), 763780. doi:10.1017/S1355770X12000290

Iqbal, K., \& Roy, P. K. (2015). Climate change, agriculture and migration: Evidence from bangladesh. Climate Change Economics, 6(2), 15006. doi:10.1142/S2010007815500062

Jankowska, M. M., Lopez-Carr, D., Funk, C., Husak, G. J., \& Chafe, Z. A. (2012). Climate change and human health: Spatial modeling of water availability, malnutrition, and livelihoods in mali, africa. Applied Geography, 33, 4-15. doi:10.1016/j.apgeog.2011.08.009

Jennings, C. L., Julia A.and Gray. (2015). Climate variability and human migration in the netherlands, 1865-1937. Population and Environment, 36(3), 255-278. doi:10.1007/s11111-014-0218-z

Kim, S.-Y., Lee, J.-T., Hong, Y.-C., Ahn, K.-J., \& Kim, H. (2004). Determining the threshold effect of ozone on daily mortality: an analysis of ozone and mortality in seoul, korea, 1995-1999. Environmental Research, 94 (2), 113119. doi:10.1016/j.envres.2003.09.006

Kniveton, D., Smith, C., \& Wood, S. (2011) Agent-based model simulations of future changes in migration flows for burkina faso. Global Environmental Change, 21, S34-S40. doi:10.1016/j.gloenvcha.2011.09.006

Knowlton, K., Rosenthal, J. E., Hogrefe, C. Lynn, B., Gaffin, S., Goldberg, R., ... Kinney, P. L. (2004). Assessing ozone-related health impacts under a changing climate. Environmental Health Perspectives, 112(15), 1557-1563. doi:10.1289/ehp.7163

Kolstad, E. W., \& Johansson, K. A. (2010). Uncertainties associated with quantifying climate change impacts on human health: a case study for diarrhea. Environmental health perspectives, 119(3), 299-305. doi:10.1289/ehp.1002060

Kumar, K. S. K., \& Viswanathan, B. (2013) Influence of weather on temporary and permanent migration in rural india. $\mathrm{Cli}$ mate Change Economics (CCE), 4(02), 1-19. doi:10.1142/S2010007813500073

Marchiori, L., Maystadt, J.-F., \& Schumacher, I. (2012). The impact of weather anomalies on migration in sub-saharan africa. Journal of Environmental Economics and Managemen, 63(3), 355-374. doi:10.1016/j.jeem.2012.02.001

Marchiori, L., \& Schumacher, I. (2011). When nature rebels: international migration, climate change, and inequality. Journal of Population Economics, 24(2), 569-600. doi:10.1007/s00148009-0274-3

Martin, M., Billah, M., Siddiqui, T., Abrar, C., Black, R., \& Kniveton, D. (2014). Climaterelated migration in rural bangladesh: a behavioural model. Population and Environment, 36 (1), 85-110. doi:10.1007/s11111-014-0207-2

Masson-Delmotte, V., Zhai, P., Pörtner, H., Roberts, D., Skea, J., Shukla, P., ... others (2018). Ipcc, 2018: Summary for policymakers (Tech. Rep.). Geneva, Switzerland.
McMichael, A., Githeko, A., Akhtar, R., Carcavallo, R., Gubler, D., Haines, A., ... Sasaki, A. (2001). Human health. In J. J. McCarthy, O. F. Canziani, N. A. Leary, D. J. Dokken, \& K. S. White (Eds.), Climate change 2001: Impacts, adaptation, and vulnerability. Cambridge: Cambridge University Press.

Meze-Hausken, E. (2000). Migration caused by climate change: how vulnerable are people inn dryland areas? Mitigation and Adaptation Strategies for Global Change, 5(4), 379-406. doi:10.1023/A:1026570529614

Mortreux, C., \& Barnett, J. (2009). Climate change, migration and adaptation in funafuti, tuvalu. Global Environmental Change, 19(1), 105-112. doi:10.1016/j.gloenvcha.2008.09.006

Nawrotzki, R. J., Hunter, L. M., Runfola, D. M., \& Riosmena, F. (2015). Climate change as a migration driver from rural and urban mexico. Environmental Research Letters, 10(11), 114023. doi:10.1088/1748-9326/10/11/114023

Nawrotzki, R. J., Riosmena, F., \& Hunter, L. M. (2013). Do rainfall deficits predict u.s.-bound migration from rural mexico? evidence from the mexican census. Population Research and Policy Review, 32(1), 129-158. doi:10.1007/s11113012-9251-8

Ocello, C., Petrucci, A., Testa, M. R., \& Vignoli, D. (2015). Environmental aspects of internal migration in tanzania. Population and Environment, 37(1), 99-108. doi:10.1007/s11111-014-0229-9

Pachauri, R. K., Allen, M. R., Barros, V. R., Broome, J., Cramer, W., Christ, R., ... van Ypserle, J.-P. (2014). Climate change 2014: Synthesis report. contribution of working groups $i$, ii and iii to the fifth assessment report of the intergovernmental panel on climate change (R. Pachauri \& L. Meyer, Eds.). Geneva, Switzerland: IPCC. doi:10013/epic.45156

Parham, P. E., \& Michael, E. (2010). Modeling the effects of weather and climate change on malaria transmission. Environmental Health Perspectives, 118(5), 620-626. doi:10.1289/ehp.0901256

Pei, Q., \& Zhang, D. (2014). Long-term relationship between climate change and nomadic migration in historical china. Ecology and Society, 19(2). doi:10.5751/ES-06528-190268

Post, E. S., Grambsch, A., Weaver, C., Morefield, P., Huang, J., Leung, L.-Y., ... others (2012). Variation in estimated ozone-related health impacts of climate change due to modeling choices and assumptions. Environmental health perspectives, 120(11), 1559-1564. doi:10.1289/ehp.1104271

Sheffield, P. E., Knowlton, K., Carr, J. L., \& Kinney, P. L. (2011). Modeling of regional climate change effects on ground-level ozone and childhood asthma. American Journal of Preventive Medicin, 41(3), 251-257. doi:10.1016/j.amepre.2011.04.017

Tagaris, E., Liao, K.-J., DeLucia, A. J., Deck, L., Amar, P., \& Russell, A. G. (2009). Potential impact of climate change on air pollution- 
related human health effects. Environmental Science \& Technology, 43(13), 4979-4988. doi:10.1021/es803650w

Van Oldenborgh, G. J., Philip, S. Y., \& Collins, M. (2005). El Niño in a changing climate: a multi-model study. Ocean Science, 1(2), 81-95. https://hal.archives-ouvertes.fr/hal -00298272/file/os-1-81-2005.pdf.

WHO. (2014). Quantitative risk assessment of the effects of climate change on selected causes of death, 2030s and 2050s. World Health Organization. 


\section{Appendices}

In the following table, brief summaries of sample of studies are provided. In the Finding column of the table, $N$ stands for negative; $P$ stands for positive effects and $N E$ stands for no effect. When climate change lead to a rise of diseases or an increase in the flow of migration, we consider it as negative effect, vice versa.

Table A1: Sample of studies

\begin{tabular}{|c|c|c|c|c|c|c|}
\hline$N^{\circ}$ & References & Scope & $\begin{array}{l}\text { Impact } \\
\text { on }\end{array}$ & Horizon & Methods & Finding \\
\hline 1 & Kim et al., 2004 & US & Health & $1990 \mathrm{~s}-2100$ & $\begin{array}{l}M= \\
(P / 100,000) * B * C R F * E\end{array}$ & $\mathrm{~N}$ \\
\hline 2 & $\begin{array}{l}\text { Deschenes et al., } \\
2009\end{array}$ & US & Health & $1972-1988$ & Regression & $\mathrm{N}$ \\
\hline 3 & $\begin{array}{c}\text { Jankowska et al., } \\
2012\end{array}$ & MALI & Health & 2025 & $\begin{array}{l}\text { multivariate linear } \\
\text { regression }\end{array}$ & $\mathrm{N}$ \\
\hline 4 & $\begin{array}{l}\text { English et al., } \\
2009\end{array}$ & US & Health & - & - & $\mathrm{N}$ \\
\hline 5 & $\begin{array}{l}\text { Caminade et al., } \\
2014\end{array}$ & Global & Health & $\begin{array}{l}2030 \mathrm{~s}, \\
2050 \mathrm{~s}, \text { and } \\
2080 \mathrm{~s}\end{array}$ & $\begin{array}{l}\text { LMM_RO monthly model, } \\
\text { MARA model, VECTRI } \\
\text { model, UMBA statistical, } \\
\text { MIASMA model }\end{array}$ & $\mathrm{N}$ \\
\hline 6 & $\begin{array}{c}\text { Sheffield et al., } \\
2011\end{array}$ & $\begin{array}{l}\text { New York } \\
\text { City }\end{array}$ & Health & $\begin{array}{l}1990 \mathrm{~s} \\
-2020 \mathrm{~s}\end{array}$ & $\begin{array}{l}M= \\
(P \div 10,000) * B * E R C\end{array}$ & $\mathrm{~N}$ \\
\hline 7 & $\begin{array}{c}\text { Parham \& } \\
\text { Michael, } 2010\end{array}$ & Tanzania & Health & 2080 & $\begin{array}{l}\text { Basic reproduction } \\
\text { number R0 of malaria }\end{array}$ & $\mathrm{N}$ \\
\hline 8 & $\begin{array}{c}\text { Tagaris et al., } \\
2009\end{array}$ & US & Health & $\begin{array}{l}2001 \text { and } \\
2050\end{array}$ & $\begin{array}{l}\text { Community Multiscale } \\
\text { Air Quality (CMAQ) }\end{array}$ & $\mathrm{N}$ \\
\hline 9 & $\begin{array}{l}\text { Bambrick et al., } \\
2008\end{array}$ & Australia & Health & 2100 & Poisson regression & $\mathrm{N}$ \\
\hline 10 & $\begin{array}{c}\text { Kolstad \& } \\
\text { Johansson, } 2010\end{array}$ & - & Health & $\begin{array}{l}2010-2039 \\
\text { and } \\
2070-2099\end{array}$ & - & $\mathrm{N}$ \\
\hline 11 & Post et al., 2012 & - & Health & $2000-2050$ & - & $\mathrm{N}$ \\
\hline 12 & WHO, 2014 & Global & Health & 2030,2050 & & $\mathrm{~N}$ \\
\hline 13 & $\begin{array}{l}\text { Curriero et al., } \\
2002 \\
\text { Hassani- }\end{array}$ & US & Health & 1973-1994 & log-linear regression & $\mathrm{N}$ \\
\hline 14 & $\begin{array}{l}\text { Mahmooei \& } \\
\text { Parris, } 2012\end{array}$ & Bangladesh & Migration & 2050 & Agent-based model & $\mathrm{N}$ \\
\hline 15 & $\begin{array}{c}\text { Barbieri et al., } \\
2010\end{array}$ & Brazil & Migration & $2025-2050$ & $\begin{array}{l}\text { Computable general } \\
\text { equilibrium } \\
\text { model-IMAGEM-B } \\
\text { (Integrated } \\
\text { Multi-Regional Applied } \\
\text { General Equilibrium } \\
\text { Model for Brazil) }\end{array}$ & $\mathrm{N}$ \\
\hline 16 & $\begin{array}{l}\text { Nawrotzki et al., } \\
2015\end{array}$ & Mexico & Migration & 1986-1999 & $\begin{array}{l}\text { Multi-level event history } \\
\text { models }\end{array}$ & $\mathrm{N}$ \\
\hline 17 & Iqbal \& Roy, 2015 & Bangladesh & Migration & $1990-2030$ & $\begin{array}{l}\text { OLS, fixed effects, IV } \\
\text { models }\end{array}$ & $\mathrm{N}$ \\
\hline 18 & $\begin{array}{c}\text { Mortreux \& } \\
\text { Barnett, } 2009\end{array}$ & Tuvalu & Migration & 2007 & $\begin{array}{l}\text { Semi-structured } \\
\text { interviews }\end{array}$ & No \\
\hline 19 & Jennings, 2015 & $\begin{array}{l}\text { Nether- } \\
\text { lands }\end{array}$ & Migration & $1865-1937$ & $\begin{array}{l}\text { Discrete-time event } \\
\text { history model }\end{array}$ & $\mathrm{P} / \mathrm{N}$ \\
\hline 20 & $\begin{array}{c}\text { Nawrotzki et al., } \\
2013\end{array}$ & $\begin{array}{l}\text { US- } \\
\text { Mexico }\end{array}$ & Migration & 2000 & Multilevel model & $\mathrm{N}$ \\
\hline
\end{tabular}


Table A1 (Cont.): Sample of studies

\begin{tabular}{|c|c|c|c|c|c|c|}
\hline$N^{\circ}$ & References & Scope & $\begin{array}{l}\text { Impact } \\
\text { on }\end{array}$ & Horizon & Methods & Finding \\
\hline 21 & Ocello et al., 2015 & Tanzania & Migration & 2008-2009 & Logistic regression models & $\mathrm{P} \mathrm{N}$ \\
\hline 22 & $\begin{array}{l}\text { Abel et al., } 2013 \\
\text { Kumar \& }\end{array}$ & U.K. & Migration & 2060 & Bayesian Models & $\mathrm{NE}$ \\
\hline 23 & $\begin{array}{l}\text { Viswanathan, } \\
2013\end{array}$ & India & Migration & $2007-2008$ & Discrete choice model & $\mathrm{N}$ \\
\hline 24 & Feng et al., 2010 & $\begin{array}{c}\text { US- } \\
\text { Mexico }\end{array}$ & Migration & 2080 & Two-stage model & $\mathrm{N}$ \\
\hline 25 & $\begin{array}{l}\text { Pei \& Zhang, } \\
2014\end{array}$ & China & Migration & & The Push-Pull model & $\mathrm{N}$ \\
\hline 26 & $\begin{array}{l}\text { Fussell et al., } \\
2014\end{array}$ & $\begin{array}{l}\text { New } \\
\text { Orleans }\end{array}$ & Migration & $\begin{array}{l}1999-2004 \\
\text { and } \\
2007-2009\end{array}$ & $\begin{array}{l}\text { Two matrices of } \\
\text { county-to-county }\end{array}$ & $\mathrm{N}$ \\
\hline 27 & Black et al., 2011 & - & Migration & & & $\mathrm{N}$ \\
\hline 28 & $\begin{array}{c}\text { Cattaneo \& } \\
\text { Massetti, } 2015\end{array}$ & Ghana & Migration & $\begin{array}{l}2010 \text { and } \\
2011\end{array}$ & $\begin{array}{l}\text { New Economics of Labor } \\
\text { Migration }\end{array}$ & $\mathrm{N}$ \\
\hline 29 & $\begin{array}{c}\text { Marchiori \& } \\
\text { Schumacher, } 2011\end{array}$ & - & Migration & 2050 & $\begin{array}{l}\text { Two-country, general } \\
\text { equilibrium, overlapping- } \\
\text { generations model }\end{array}$ & $\mathrm{N}$ \\
\hline 30 & $\begin{array}{l}\text { Martin et al., } \\
2014\end{array}$ & Bangladesh & Migration & & $\begin{array}{l}\text { Semi structured } \\
\text { interviews }\end{array}$ & $\mathrm{N}$ \\
\hline 31 & $\begin{array}{l}\text { Kniveton et al., } \\
2011\end{array}$ & $\begin{array}{l}\text { Burkina } \\
\text { Faso }\end{array}$ & Migration & $2010-2060$ & Agent-based model & $\mathrm{N}$ \\
\hline 32 & $\begin{array}{l}\text { Meze-Hausken, } \\
2000\end{array}$ & $\begin{array}{l}\text { Northern } \\
\text { Ethiopia }\end{array}$ & Migration & $1888-1992$ & Survey & $\mathrm{NE}$ \\
\hline
\end{tabular}

